\title{
Self-archiving dermatology articles
}

\author{
Robert P. Dellavalle, MD, PhD, MSPH, ${ }^{\mathrm{a}, \mathrm{b}}$ Marcus A. Banks, MLIS,${ }^{\mathrm{c}}$ and Jeffrey I. Ellis, MD ${ }^{\mathrm{d}, \mathrm{e}_{*}}$ \\ Denver, Colorado; San Francisco, California; and Brooklyn and Manbasset, New York
}

$\mathbf{M}$ anuscripts, like embryos and tumors, develop in stages (Table I), and dermatology authors increasingly expose this development to examination by self-archiving - that is, by posting manuscripts or published papers on personal Web sites and in public repositories (Table II) ${ }^{1}$ before, simultaneous with, or after publication in academic journals. ${ }^{2-5}$ When authors publish in closed-access traditional journals, self-archiving makes their work accessible to those without subscriptions or medical-library access (including peers in developing countries and the lay public) and may also improve the preservation of digital content ${ }^{6,7} ; \mathrm{a}$ downside of self-archiving, however, remains the potential loss of revenue to scientific societies dependent on subscriptions or manuscript access fees. ${ }^{8}$

When deciding whether and, if so, at what stage(s), to self-archive, authors should examine the policies of journals to which the final manuscript will be or has been submitted. Although few do so, publishers may prohibit self-archiving. In other cases, self-archiving

From the Dermatology Service, Veterans Affairs Medical Center ${ }^{\mathrm{a}}$ and the Departments of Dermatology and Preventive Medicine, University of Colorado Denver School of Medicine ${ }^{\mathrm{b}}$; Kalmanovitz Library and Center for Knowledge Management, University of California, San Francisco ${ }^{c}$; the Department of Dermatology, SUNY Downstate Medical Center, Brooklyn, ${ }^{d}$ and the Department of Medicine, Division of Dermatology, North Shore Hospital, Manhasset, ${ }^{\mathrm{e}}$ New York.

*Dr Ellis is the founder of JournalReview.org.

Funding source: This study began with Colorado Health Informatics Collaboration interdisciplinary discourse supported by academic enrichment funds from the University of Colorado Denver, School of Medicine.

Disclosures: $\operatorname{Dr}$ Dellavalle is dermatology section editor for UpToDate and an unpaid advisor to www.JournalReview.org. He serves on the editorial boards of the following journals: $J A A D$, Archives of Dermatology, Journal of Investigative Dermatology, BMC Dermatology, The Open Dermatology Journal, BMC Research Notes, and the Journal of Medical Case Reports. Mr Banks is the former editor-in-chief of Biomedical Digital Libraries. Dr Ellis is the founder of www.JournalReview.org.

Reprint requests: Robert P. Dellavalle, MD, PhD, MSPH, Department of Dermatology, University of Colorado at Denver and Health Sciences Center, PO Box 6510, Mail Stop F703, Aurora, CO 80045-0510. E-mail: robert.dellavalle@uchsc.edu.

J Am Acad Dermatol 2008;59:1086-8.

0190-9622/\$34.00

(C) 2008 by the American Academy of Dermatology, Inc.

doi:10.1016/j.jaad.2008.07.015
Table I. Stages of manuscript development

\begin{tabular}{|c|c|}
\hline Draft & $\begin{array}{l}\text { A composition (manuscript) before } \\
\text { submission; ideally drafts undergo } \\
\text { multiple rounds of development } \\
\text { and revision. }\end{array}$ \\
\hline Submission & $\begin{array}{l}\text { "Finished" manuscript submitted for } \\
\text { publication consideration }\end{array}$ \\
\hline Revision & $\begin{array}{l}\text { Manuscript changed in response to } \\
\text { comments by the peer reviewers } \\
\text { and editor }\end{array}$ \\
\hline $\begin{array}{l}\text { Accepted } \\
\text { manuscript }\end{array}$ & Manuscript accepted for publication \\
\hline $\begin{array}{l}\text { Copyedited } \\
\text { manuscript }\end{array}$ & $\begin{array}{l}\text { Manuscript refined by journal staff } \\
\text { or contractors, largely for } \\
\text { correctness, clarity, conciseness, } \\
\text { and consistency with journal style } \\
\text { and format }\end{array}$ \\
\hline $\begin{array}{l}\text { Uncorrected } \\
\text { proof }\end{array}$ & $\begin{array}{l}\text { Preliminary version of the formatted } \\
\text { paper, to be checked by the } \\
\text { author(s) and editor(s) }\end{array}$ \\
\hline $\begin{array}{l}\text { Preprint or } \\
\text { corrected } \\
\text { proof }\end{array}$ & $\begin{array}{l}\text { Corrected version of the above; at } \\
\text { this stage, issue and page } \\
\text { numbers may or may not be } \\
\text { assigned. }\end{array}$ \\
\hline $\begin{array}{l}\text { Forthcoming } \\
\text { article }\end{array}$ & $\begin{array}{l}\text { An accepted article in line for print } \\
\text { publication; some journals, such } \\
\text { as the } J A A D \text {, publish some } \\
\text { forthcoming articles as an } \\
\text { electronic publication ahead of } \\
\text { print. }\end{array}$ \\
\hline $\begin{array}{l}\text { E-publication ahead } \\
\text { of print }\end{array}$ & $\begin{array}{l}\text { Final formatted paper available via } \\
\text { the journal's Web site }\end{array}$ \\
\hline $\begin{array}{l}\text { Postprint or article } \\
\text { on paper }\end{array}$ & Paper in the print journal \\
\hline
\end{tabular}

before publication may decrease the likelihood of a manuscript's acceptance. SHERPA/RoMEO ${ }^{6}$ lists the self-archiving policies of more than 300 journals. ${ }^{?}$ Volunteers contribute SHERPA/RoMEO data, so there is no guarantee that it is current; prospective authors should verify a publisher's current policies with the publisher directly.

We commend the Journal of the American Academy of Dermatology's (JAAD's) publisher, Elsevier, and its owner, the American Academy of Dermatology (AAD), for the JAAD's permissive selfarchiving policy. ${ }^{10-12}$ This policy allows JAAD authors to post (1) preprints prior to submission and (2) articles 
Table II. Selected online repositories listed alphabetically

Repository (Year initiated)
arXiv: http://arxiv.org/ (2005)
The Depot: http://depot.edina.ac.uk/ (2007)
DSpace at MIT: http://dspace.mit.edu/ (2003)
E-LIS: http://eprints.rclis.org/ (2002)
JournalReview.org: www.journalreview.org (2004)

MERLOT: http://www.merlot.org/merlot/index.htm (1997)

PubMed Central www.pubmedcentral.nih.gov/ (2001)

University of California eScholarship Repository: http://repositories.cdlib.org/escholarship/ (2005)
Description*

"E-print service in the fields of physics, mathematics, nonlinear science, computer science, and quantitative biology."

"The Depot has two main services on offer: 1. a re-direct service, with the Depot acting as a gateway, especially to repositories at UK universities (institutional repositories) 2. a deposit service for e-prints, with the Depot acting as a national repository for researchers not yet having an institutional repository in which to deposit their papers, articles, and book chapters (e-prints)."

"MIT's online institutional repository-built to save, share, and search MIT's digital research materials."

"Research in computing and library and information science." JournalReview.org provides authors a means of adding supplemental content to published work and colleagues a medium for discussing published literature.

"MERLOT's vision is to be a premiere online community where faculty, staff, and students from around the world share their learning materials and pedagogy."

Official repository of published research funded by the US National Institutes of Health (NIH). All investigators shall "submit or have submitted for them to the National Library of Medicine's PubMed Central an electronic version of their final, peer-reviewed manuscripts upon acceptance for publication, to be made publicly available no later than 12 months after the official date of publication." ${ }^{11}$

"The eScholarship Repository... enables the rapid and lowcost creation, management, and dissemination of journals, peer-reviewed series, working papers, discussion papers series, and other electronic forms of scholarship by UC researchers."

*Descriptions of numerous additional repositories can be found at the Registry of Open Access Repositories (ROAR, http:// roar.eprints.org/index.php?prev=Prev\&page=all). Descriptive quotes were taken from the respective websites listed.

Table III. Glossary

\begin{tabular}{ll}
\hline ArXiv & $\begin{array}{c}\text { Large electronic archive of physics, mathematics, computer science and quantitative } \\
\text { biology papers (www.arXiv.org) } \\
\text { The storing of a digital version of an author's work on a publicly accessible Web site (eg, } \\
\text { the author's Web site, author's institution's Web site, or another digital repository. } \\
\text { Increased citation of a manuscript. }\end{array}$ \\
$\begin{array}{l}\text { Citation advantage } \\
\text { Digital Object Identifier (DOI) }\end{array}$ & $\begin{array}{l}\text { A unique identification number purchased by a publisher for the work } \\
\text { Open access }\end{array}$ \\
the efforts of authors (a.k.a. the green road to open access) or publishers (a.k.a. the \\
gold road to open access)
\end{tabular}

*For example, our recent $J A A D$ article, "Frequently asked questions regarding self-plagiarism: How to avoid recycling fraud" (J Am Acad Dermatol. 2007;57:527)" has the following DOI: doi:10.1016/j.jaad.2007.05.018.

after submission on their personal Web sites and their institutions' Web sites if the posting includes the article's citation and either a link to the $J A A D$ 's home page or the article's digital object identifier (DOI) - a unique identification number purchased by a publisher to identify the work on the Internet persistently. 
The additional work for authors constitutes a minor barrier to self-archiving. Although self-archiving is not difficult, it may take 10 to 20 minutes to upload one's first paper and 10 or fewer minutes to upload subsequent papers. ${ }^{13}$ Despite the ease of self-archiving, and the enhanced exposure to a paper that self-archiving affords, many authors remain unaware of its benefits. ${ }^{14}$ Because of the lack of familiarity, medicine has been slow to adopt new publishing models. However, now, like computer scientists and physicists who have been self-archiving articles for many years, ${ }^{15}$ all physicians, including dermatologists, should consider self-archiving their articles more routinely and promoting journals with permissive self-archiving policies (Table III). ${ }^{16}$

\section{REFERENCES}

1. National Institutes of Health. Revised Policy on Enhancing Public Access to Archived Publications Resulting from NIH-Funded Research. Available at: http://grants.nih.gov/grants/guide/noticefiles/NOT-OD-08-033.html. Accessed May 21, 2008.

2. Harnad S. The self-archiving initiative. Nature 2001;410:1024-5. Available at: http://www.nature.com/nature/debates/e-access/ Articles/harnad.html. Accessed May 21, 2008.

3. Eysenbach G. The impact of preprint servers and electronic publishing on biomedical research. Curr Opin Immunol 2000; 12:499-503.

4. Eysenbach G. Challenges and changing roles for medical journals in the cyberspace age: electronic pre-prints and epapers. J Med Internet Res 1999;1:e9.

5. Guterman L. Harvard faculty adopts open access requirement. The Chronicle of Higher Education News Blog; February 12, 2008. Available at: http://chronicle.com/news/article/3943/harvardfaculty-adopts-open-access-requirement. Accessed May 21, 2008.
6. Wren JD, Johnson KR, Crockett DM, Heilig LF, Schilling LM, Dellavalle RP. Uniform resource locator decay in dermatology journals: author attitudes and preservation practices. Arch Dermatol 2006;142:1147-52.

7. Dellavalle RP, Hester EJ, Heilig LF, Drake AL, Kuntzman JW, Graber $M$, et al. Going, going, gone: lost Internet references. Science 2003;302:787-8.

8. Harnad S. 125 Provosts For, 10 Against Federal Research Public Access Act Self-Archiving Mandate. Open Access Archivangelism; Sept. 25, 2006. Available at: http://openaccess.eprints.org/ index.php?/archives/135-guid.html. Accessed May 21, 2008.

9. SHERPA/RoMEO. Publisher Copyright Policies \& Self-Archiving. Available at: http://www.sherpa.ac.uk/romeo.php. Accessed May 5, 21, 2008.

10. Authors-Elsevier. What rights do I retain as a journal author? Available at: http://www.elsevier.com/wps/find/authorsview. authors/copyright\#whatrights. Accessed May 21, 2008.

11. Authors-Elsevier. Electronic Preprints. Available at: http://www. elsevier.com/wps/find/authorshome.authors/preprints. Accessed May 21, 2008.

12. Bernhard J. Authors' rights. Available at: http://www.eblue. org/webfiles/images/journals/ymjd/rights.pdf. Accessed May 21, 2008.

13. Carr L, Harnad S. Keystroke economy: a study of the time and effort involved in self-archiving. Available at: http://eprints. ecs.soton.ac.uk/10688/. Accessed May 21, 2008.

14. Swan A. Open access self-archiving: an introduction. Available at: http://eprints.ecs.soton.ac.uk/11006/. Accessed May 21, 2008.

15. Cornell University Library. ArXiv.org: Open access to 466,879 eprints in physics, mathematics, computer science and quantitative biology. Available at: http://arxiv.org/. Accessed May 21, 2008.

16. Harnad $S$, Brody $T$, Vallières $F$, Carr $L$, Hitchcock $S$, Gingras $Y$, et al. The access/impact problem and the green and gold roads to open access. Available at: http://dx.doi.org/10.1016/ j.serrev.2004.09.013. Accessed March 6. 2008. Shorter version available at Nature Web Focus: http://www.nature.com/ nature/focus/accessdebate/21.html. Accessed May 21, 2008.

\section{What's new online?}

Click on www.eblue.org today to find out how you can link from cited references to abstracts and full text of other participating journals. 